\title{
Sedimentary evidence for a mid-Holocene iceberg-generated tsunami in a coastal lake, west Greenland
}

\author{
Antony J. Long ${ }^{1} \cdot$ Witold szczuciński ${ }^{2} \cdot$ Thomas Lawrence $^{1}$
}

Received: 8 September 2015/Accepted: 10 October 2015/Published online: 20 November 2015

(C) The Author(s) 2015. This article is published with open access at Springerlink.com

\begin{abstract}
We report sedimentological evidence for a tsunami from a coastal lake at Innaarsuit, Disko Bugt (west Greenland), which was most likely generated by a rolling iceberg. The tsunami invaded the lake c. 6000 years ago, during a period of time when relative sea level (RSL) was falling quickly because of isostatic rebound. We use the background rate of RSL fall, together with an age model for the sediment sequence, to infer a minimum wave runup during the event of c. $3.3 \mathrm{~m}$. The stratigraphic signature of the event bears similarities to that described from studies of the early-Holocene Storegga slide tsunami in Norwegian coastal basins. Conditions conducive to iceberg tsunami include a supply of icebergs, deep water close to the shore, a depositional setting protected from storms or landslide tsunami, and a coastal configuration that has the potential to amplify the height of tsunami waves as water depths shallow and the waves approach and impact the coast. Future warming of polar regions will lead to increased calving and iceberg production, at a time when human use of polar coasts will also grow. We predict, therefore, that iceberg-generated tsunami will become a growing hazard in polar coastal waters, especially in areas adjacent to large, fast-flowing, marine-terminating ice streams that are close to human populations or infrastructure.
\end{abstract}

Electronic supplementary material The online version of this article (doi:10.1007/s41063-015-0007-7) contains supplementary material, which is available to authorized users.

Antony J. Long

a.j.long@durham.ac.uk

1 Department of Geography, Durham University, Durham DH1 3LE, UK

2 Institute of Geology, Adam Mickiewicz University in Poznan, Maków Polnych 16, 61-606 Poznań, Poland
Keywords Iceberg · Tsunami - Isolation basin - Coastal lake $\cdot$ Relative sea level · Natural hazard · Greenland

\section{Introduction}

Most tsunamis are generated on active plate boundaries, triggered by earthquake-generated rapid vertical seabed movement (e.g. [47, 56]). Other, less common sources include submarine landslides (e.g. [16]), subaerial rockfalls or landslides that enter in the sea (e.g. $[15,23]$ ), volcanic eruptions (e.g. [46]), rapid large-scale air pressure disturbances-called also meteotsunami (e.g. [44, 57]) and, most rarely, cosmic asteroid impact (e.g. [61]).

Icebergs provide a further potential source of tsunami in polar regions. Here, we use the term "iceberg-generated tsunami" to capture the range of potential iceberg motions (e.g. rocking, capsizing, rolling, collapsing) that can generate waves. Tsunamis generated by icebergs are frequently observed in parts of Antarctica and Greenland, where they routinely have wave heights of $2 \mathrm{~m}$ or so [1, 2, 40]. However, their occurrence and geomorphic significance over longer (Holocene) timescales have not previously been studied.

As part of a study reconstructing relative sea-level (RSL) changes in the Innaarsuit area of Disko Bugt, west Greenland (Fig. 1), Long et al. [37] identified an anomalous sand unit within lake muds, deposited a few centuries after basin isolation from the sea by RSL fall. Here, we reappraise this sand unit with a focus on its potential significance as a palaeo-indicator of a past iceberg-generated tsunami. We consider this re-analysis is timely for several reasons. First, there is a growing awareness of the potential impact of iceberg-generated waves (due to rolling and breaking) on human activity on land and sea. This has been 


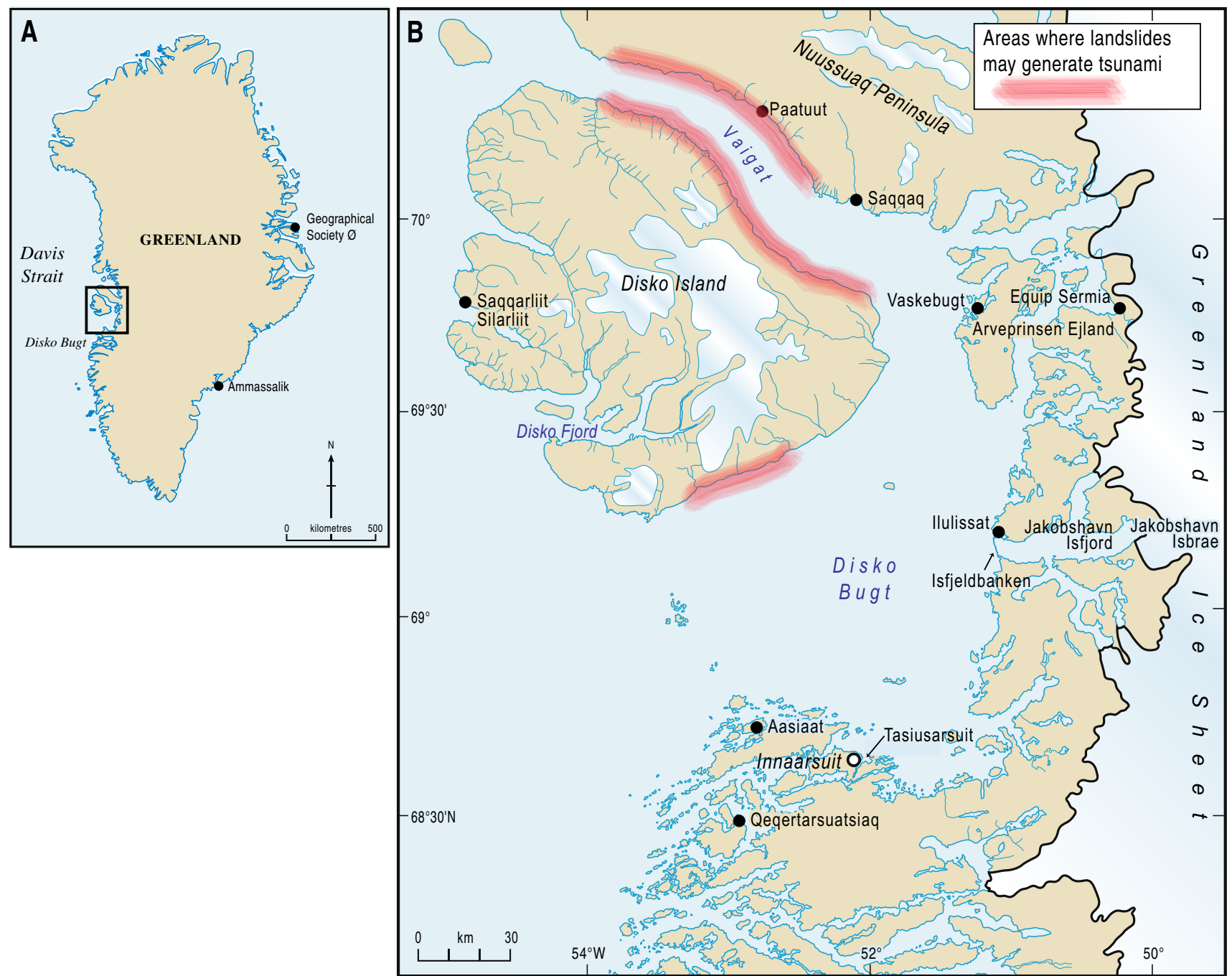

Fig. 1 Location map of Greenland and Disko Bugt, showing place names mentioned in the text and areas of potential tsunami-generating landslides (from [15]. The Innaarsuit study site is located on the south coast of Disko Bugt

aided by some spectacular amateur video footage shot from Greenland (e.g. https://www.youtube.com/watch?v= $2 \mathrm{NvwlnKVtU}$ ). Second, a recent acceleration in calving flux from many Greenland glaciers (e.g. [52, 62]) has been accompanied by several direct measurements of several long waves caused by iceberg generation/roll [1, 2], although no evidence of their sedimentary impact on coastal lakes has been reported to date. Third, recent reports from Antarctica have speculated on the wider potential contribution of iceberg tsunami in accelerating the break-up of large ice shelves, including Larsen B and Wilkins ice shelves [34, 41, 55]. Fourth, as discussed below, coastal lakes are excellent repositories of evidence for tsunami generated by a subduction earthquakes and submarine landslides (e.g. [6]; Hutchinson et al. 2002); as such they have a proven potential to do the same with regard to iceberg-related processes.

We present a new suite of field and laboratory analyses that help to characterise the lake deposit and establish approximate minimum tsunami wave run-up using the rate of mid-Holocene RSL fall. We review other isolation basin records within Disko Bugt and conclude that local tsunami impact may have been more frequent than previously thought. We conclude by reflecting that global warming will lead to increased calving, at a time when human use of the polar coast will also grow. Iceberg-generated tsunami will become a growing hazard in polar coastal waters, especially in areas adjacent to large, fast-flowing marineterminating ice streams that are close to human populations or infrastructure. 


\section{Previous work}

\section{Iceberg-generated tsunami}

When an iceberg tilts, rocks, capsizes, rolls or disintegrates, it will generate waves the dimensions of which will depend on the size and geometry of the iceberg, the direction and speed of the rotation, as well as the water depth at the point of rotation and the wider local bathymetry. Based on these parameters, MacAyeal et al. [42] developed a simple rule of thumb that relates tsunami wave height to iceberg thickness. This predicts that the openwater tsunami height has an upper limit of $0.01 \mathrm{H}$ where $H$ is the initial iceberg thickness. Thus, a tsunami with a solitary surface wave amplitude of $10 \mathrm{~m}$ in open water could be caused by the rolling of an iceberg with a thickness of $1000 \mathrm{~m}$. MacAyeal et al. [42] note that icebergs of this size, with tsunami waves of approximately this amplitude, have been observed in the vicinity of Jakobshavn Isbrae (Sermeq Kujalleq), a large marine-terminating ice stream in west Greenland and one of the most prodigious generators of icebergs on the planet (e.g. [2]).

Icebergs generated from thick ice tongues, such as those associated with marine-terminating glaciers in Greenlandic fjords, have a greater potential for generating large tsunami than the generally thinner ice shelves that are common in Antarctica [42]. However, even relatively small icebergs have the potential to generate large tsunamis, especially where the seabed bathymetry and coastal topography act to amplify wave height (e.g. [17]).

\section{Tsunami hazard in Greenland}

Iceberg tsunamis are a well-known coastal hazard in parts of Greenland. Indeed, on the outskirts of the town of Ilulissat (west Greenland), which stands at the mouth of the Jakobshavn Isfjord (Kangia), public notices draw attention to the regular threat to life of iceberg tsunami (Fig. 2). But icebergs are not the only source of tsunami that may impact Greenland and other polar regions, where two other processes can also be important: those associated with terrestrial landslides that terminate in the sea, and far-field tsunamis that are generated by an earthquake or submarine landslide, for instance the early-Holocene Storegga slide tsunami that originated from offshore of Norway and which impacted Norway, Scotland, northeast England, as well as east Greenland [16, 28, 58].

In many parts of Greenland, a combination of geological setting, permafrost, glacier ice, steep ground and freezethaw cycles contribute to high terrestrial landslide risk.
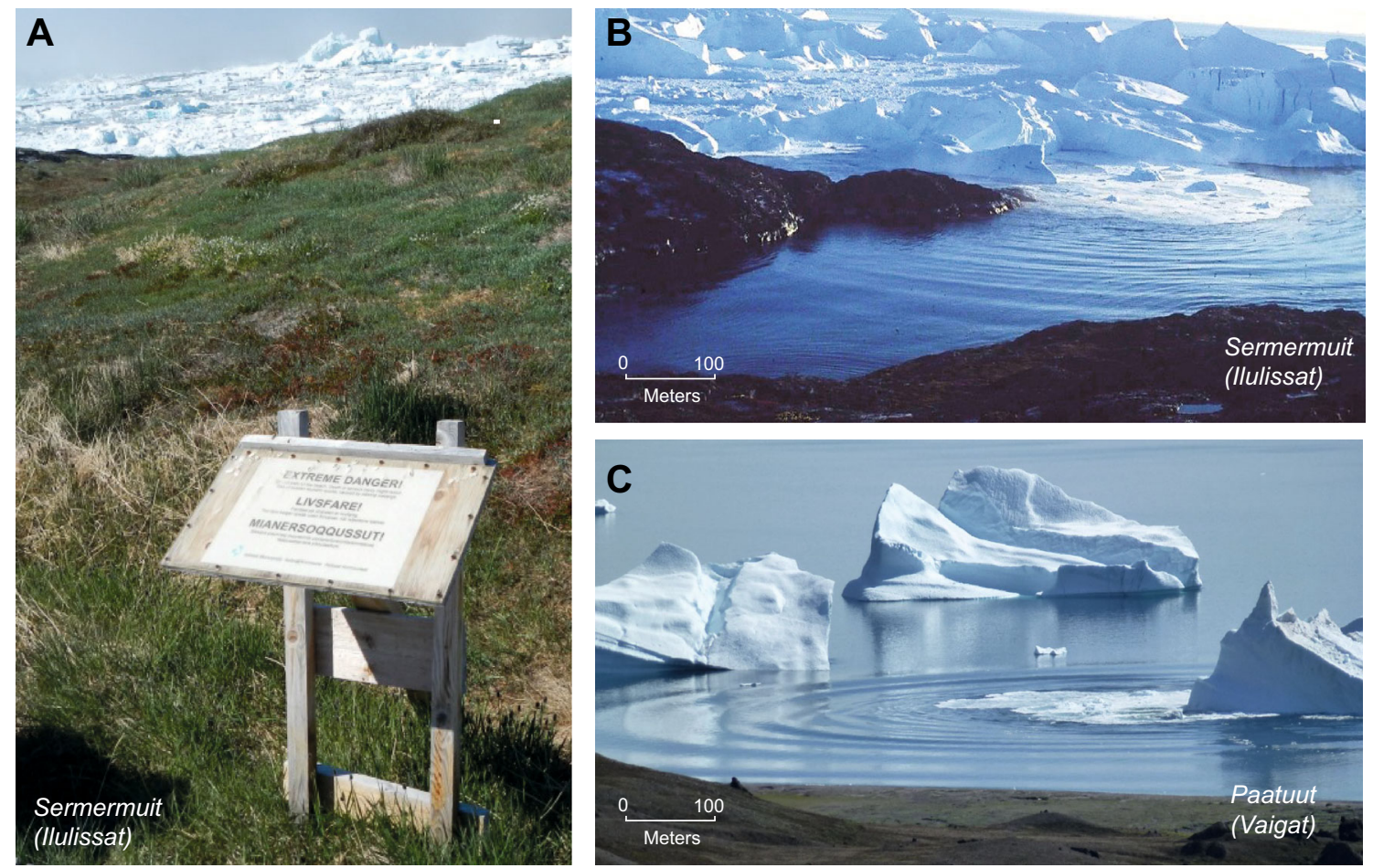

Fig. 2 Iceberg tsunami hazard in Disko Bugt, west Greenland. a Public warning notice of the threat of iceberg-generated tsunami, posted by the Ilulissat Municipality. Sign reads "EXTREME DANGER! Do not walk on the beach. Death or serious injury might occur. Risk of sudden tsunami waves, caused by calving icebergs". b Example of small iceberg-generated waves from Ilulissat (close to site of A, credit Dr David Roberts)) and from near to Paatuut (c) 
This is especially so in the Nuussuaq Basin in central west Greenland (Fig. 1), where a sequence of weakly consolidated Cretaceous sediments are capped by Palaeogene basalts (Pedersen et al. [49]). These geological conditions mean that certain areas of Disko Island, Nuussuaq and Svartenhuk Halvø are strongly affected by landslides (rock falls, slides and rock avalanches) that can generate large tsunami (Fig. 1).

The most recent landslide-triggered tsunami in Disko Bugt happened in the mid-afternoon of November 21, 2000, when residents of the coastal village of Saqqaq, located in Vaigat (northern Disko Bugt, Fig. 1) noted abnormal waves in the harbour. A subsequent survey by Pedersen et al. [49] and Dahl-Jensen et al. [15] revealed that the waves were caused by a landslide that entered the sea c. $40 \mathrm{~km}$ northwest at Paattut. The escarpment that failed at the head of the slide reached c. $1400 \mathrm{~m}$ above sea level (asl), delivering an estimated 30 million $\mathrm{m}^{3}$ of sediment into the sea. Photographs taken after the event indicate a dark stripe along the coast where low-lying snow, below about $50 \mathrm{~m}$ asl, was washed away by the tsunami. Locally the resulting tsunami had a height of $50 \mathrm{~m}$. Several icebergs were washed inland and stranded 300-700 m from the coast, with debris (sediment and icebergs) scattered across an alluvial fan up to $800 \mathrm{~m}$. The tsunami was the largest reported in Vaigat during at least the last 500 years and field observations show the impact of the event was limited to the U-shaped Vaigat fjord [15]. Buchwal et al. [12] suggest that climatic factors likely had a role in influencing the event, with the highest precipitation and thickest permafrost active layer on record observed in the months leading up to the event.

\section{The stratigraphic signature of tsunami in coastal lakes}

Coastal lakes have the potential to act as quiet-water depositories within which evidence for past tsunami can be preserved. In British Columbia, for example, Hutchinson et al. [29] record three layers of sand within a sequence of muddy gyttja in a core collected from Deserted Lake, located close to present sea level at the head of a fjord on the central west coast of Vancouver Island. The authors attribute these sands to tsunamis created by earthquakes at the Cascadia subduction zone, c. 2600, 1600 and 300 years ago. Other examples from active plate boundaries of modern and Holocene tsunami deposits identified in coastal lakes include those from Canada [60], Japan [54] and Chile $[33,59]$. On the passive coastal margins of northwest Europe, stratigraphic evidence for the AD 1755 Lisbon tsunami is described from a coastal pond on the Scilly Isles (southwest English Channel) by Foster et al. [20], whilst inundation of coastal lakes by the early-Holocene Storegga landslide is reported from a number of sites in Norway (e.g. [6]; Romundset et al. 2011).

The early-Holocene Storegga tsunami, triggered by a large $\left(3000 \mathrm{~km}^{3}\right)$ submarine landslide off southwest Norway, is dated to $8120-8175$ cal a BP [8]. Tsunami models predict that it would have struck the east coast of Greenland with a run-up of 3-5 m (Harbitz [26]). Wagner et al. [58] report evidence of the Storegga tsunami impacting what was, at the time of the event, a marine basin with water depths of 15-35 m located in NE Greenland. The sedimentary evidence of the tsunami comprises a $0.72 \mathrm{~m}$ thick sandy layer with an erosive base and distinct variations in grain size distribution. In addition, in a study of lake stratigraphies in the Ammassalik area of SE Greenland, Long et al. [38] record a distinct sand unit within coastal lake stratigraphy that was deposited around the time of the Storegga tsunami.

The abrupt inundation of quiet-water lacustrine settings can have a significant impact on the nature of the preexisting sediment body, and cause the deposition of a complex range of deposits associated with the tsunami and the immediate post-tsunami period. Bondevik et al. [6] developed an erosional and depositional model for tsunami, based on their analysis of the impact of the Storegga tsunami as it inundated coastal basins in Norway. We use this model as a base-line against which we compare the stratigraphic signature of potential tsunami in Greenland lakes.

The typical stratigraphic signatures of tsunami deposits in lakes, as described by Bondevik et al. [6], include;

(1) An erosional unconformity underlies the tsunami deposit. Typically, the erosion increases towards the seaward part of the basin, due to high lee-side turbulence as the tsunami crossed the shallow lake threshold resulting in high lake bed shear velocities. These processes may erode lake sediments accumulated during several thousand years prior to the event.

(2) The lowermost tsunami sand is typically a graded or massive sand, suggesting rapid deposition from suspension, and may also contain marine microfossils. The sand thins and fines in a landward direction.

(3) Above the sand can be coarse organic detritus with rip-up clasts, termed an "organic conglomerate", and finer organic detritus. Some of this is derived from the lake bed itself, and some is inwashed from the surrounding area (e.g. [8]). After the final withdrawal of the tsunami, fines settle out from suspension and this may lead to deposition of a thin, laminated silt above the main tsunami deposits. This deposit is thought to have formed in anoxic bottomwater conditions with reduced bioturbation caused 
by salt-water remaining in the basin for a period after the tsunami.

(4) Basins that are higher above sea level at the time of the event typically record only one sand unit, whereas lower basins may record several sand units separated by organic detritus, reflecting distinct wave trains that impact lower basins.

(5) In the case of the Norwegian basins, the typical Storegga tsunami sand thickness is $20-100 \mathrm{~cm}$.

Bondevik et al. [6] also consider alternative explanations for these types of lake deposits. They note that the overall geometry of the basin stratigraphy precludes flash flood deposits or sediment slumping from the lake sides, whilst the presence of marine microfossils indicates a marine origin for the deposits. Moreover, they observe that storm surge deposits normally reach only a small height above normal tide levels and cannot explain the inundation of basins that lie many metres above the contemporary sea level.

It is important to note, however, that the stratigraphic model described above is developed from a large, sea-floor generated tsunami. This model may differ to one applicable to a tsunami generated by an iceberg or a local landslide that reached the sea. Tsunami modelling suggests that the Storegga tsunami had a wavelength of c. 600-800 km [7]. In contrast, iceberg-generated tsunami differs because the energy released is smaller. The origin of these waves is usually in relatively shallow water, so the wavelengths are shorter than in large earthquake-generated tsunamis. This means that wave energy dissipates rapidly and their impacts tend to be recorded only relatively close to the tsunami source. However, seabed topography has the potential to amplify tsunami height at the local scale, especially on polar coasts that are typically characterised by areas of high relief. Landslide-generated tsunami is also capable of generating large waves, notably where they enter the sea in topographically restricted areas. Thus, in the case of the Paatuut tsunami, local residents at Saqqaq recorded multiple waves for nearly $2.5 \mathrm{~h}$. The long duration of the waves must have been due to reflection on multiple occasions by the steep sides of the Vaigat fjord [15].

There are other factors that may also mean that the stratigraphic model of Bondevik et al. [6] requires adaption for Greenland. For example, the sedimentary signal of a tsunami will vary depending on local ground conditions, including whether there is lake and/or sea ice, or whether the ground is frozen or snow-covered. Romundset and Bondevik [53] note that these factors could reduce a tsunami's erosive capability and hence the availability of sediment for erosion from nearshore and possibly beach shoreface sources. Rip-up clasts from terrestrial sources would not be expected in such conditions. Tsunami grain size differences might also be expected for a winter tsunami strike; tsunami sediment deposited on ice would melt out in a complex manner, with variable sediment thicknesses and more irregular grading to the tsunami sand [53].

Another characteristic of Greenland coastal lakes is that they typically have low sedimentation rates compared with Norwegian lakes, and this will influence the stratigraphic signature of a tsunami. Low sedimentation rates in Greenland caused by low organic productivity partly reflect the length of seasonal ice-cover and frozen catchments, and also low lake temperatures and nutrient availability. Bindler et al. [4] and Malmquist et al. [43] use ${ }^{210} \mathrm{~Pb}$ and ${ }^{137} \mathrm{Cs}$ to determine typical sedimentation rates of between 0.12 and $3.7 \mathrm{~mm}$ year for lake deposits accumulated in the last 100-150 years. Over Holocene timescales, Fredskild [21] states that typical Greenland lake sedimentation rates are between 0.13 and $0.37 \mathrm{~mm}$ year (similar values are also provided by Eisner et al. [19] and Bennike [3]). Greenland lake deposits are therefore often thin and can also be very soft, with a high water content.

\section{Study site}

The study site of Innaarsuit is located on the south shores of Disko Bugt, a large marine embayment on the west coast of Greenland (Fig. 2). At the Last Glacial Maximum, the ice sheet extended across the entire bay. At or shortly after the start of the Holocene (c. 11,700 cal a BP), the ice sheet margin was located at the eastern mouth of Disko Bugt, before retreating rapidly to reach the eastern shores of the bay by c. 11,000-10,000 cal a BP (e.g. [31, 32, 37, 65]). Several large marine-terminating ice streams, including Jakobshavn Isbrae, discharged icebergs into the bay during this retreat phase and throughout the remainder of the Holocene. Jakobshavn Isbrae presently discharges $25-50 \mathrm{~km}^{3}$ of icebergs into Jakobshavn Isfjord each year [30, 52]. Amundson et al. [2] observed icebergs calving from the ice stream terminus with a thickness of c. $900 \mathrm{~m}$, a kilometre in lateral width and several hundred metres in the flow direction. Each iceberg rotated $90^{\circ}$ within $5 \mathrm{~min}$, displacing up to c. $0.5 \mathrm{~km}^{3}$ of water. These icebergs travel $45 \mathrm{~km}$ along the Isfjord and must then cross into Disko Bugt via the Isfjeldsbanken (Fig. 1), a shallow bank (50-300 $\mathrm{m}$ water depth) that forms a significant topographical barrier to the large icebergs [28]. The depth of the wider Disko Bugt varies between 200 and $400 \mathrm{~m}$ ([9, 13], defining an upper limit to iceberg size in coastal water of Disko Bugt. Once in Disko Bugt proper, most icebergs drift into Davis Strait via the Vaigat strait (north Disko Bugt) or along the southern coast of Disko Island. Some icebergs also drift towards or into southern Disko Bay from 
Davis Strait due to the onshore component of ocean currents to the west of Aasiaat.

Following deglaciation, land uplift caused RSL to fall across Disko Bugt during the early- and mid-Holocene [39]. At Innaarsuit, which became ice-free early in the Holocene, RSL fell from a local marine limit (the highest occurrence of marine deposits) of c. $108 \mathrm{~m}$ at $10,300-9900 \mathrm{cal}$ a BP (calibrated years before present) to reach the present sea level at c. $3500 \mathrm{cal}$ a BP [37]. Here, a prominent inlet, Tasiusarsuit (Fig. 1), extends southward $5 \mathrm{~km}$ from the open waters of Disko Bugt (Fig. 3) and the isolation basins studied by Long et al. [37] are located on the western margin of this inlet. The present-day tidal range is c. $2.5 \mathrm{~m}$ and mean high water is c. $1.1 \mathrm{~m}$ above mean sea level (MSL).

Tasiusarsuit is connected to Disko Bugt by a shallow and narrow eastern sill and a deeper western sill that has a present width of c. $150 \mathrm{~m}$. Icebergs from Disko Bugt entering Tasiusarsuit via this entrance are restricted in size by this sill. Present water depths across this sill are $>23 \mathrm{~m}$ (Fig. 3) but would have been c. $20 \mathrm{~m}$ deeper in the mid-Holocene, when RSL was higher (see below, Fig. 6). This means that there was any iceberg entering Tasiusarsuit c. $6000 \mathrm{cal}$ a BP had a maximum thickness of c. $45 \mathrm{~m}$. Inland of the sill, water depths deepen again into Tasiusarsuit proper, and offshore from the study site lakes are presently c. $50 \mathrm{~m}$ deep (implying a water depth of c. $70 \mathrm{~m}$ at c. $6000 \mathrm{cal} \mathrm{a} \mathrm{BP}$ ).

Long et al. [37] collected stratigraphic data from six lakes at Innaarsuit. Lake IV4, an isolation basin that is the focus of this study, is a kidney-shaped lake, c. $270 \mathrm{~m}$ long and $170 \mathrm{~m}$ wide and located c. $21 \mathrm{~m}$ above present MSL (Fig. 3). Water depths in the lake are c. $6 \mathrm{~m}$, with a sediment thickness between c. 1 and $1.5 \mathrm{~m}$. A stratigraphic transect of 7 hand cores (Figs. 3, 4) identified a grey-blue silty sand in the base of the lake that was deposited under marine conditions, which fines upward into a laminated, brackish-water, organic silty clay. Overlying the silty organic clay is a dark brown to grey, freshwater silty gyttja (an organic lake mud). Diatoms through this sequence record the basins' gradual isolation from the sea, which was dated to $5440 \pm 60$ BP $(6212-6447$ cal a BP) (Table 1).

Shortly after its isolation from the sea, there was a brief incursion of salt water into the basin, as indicated by diatom data. The incursion was accompanied by erosion of the underlying gyttja and the deposition of a thin $(1-4 \mathrm{~cm}$ thick) sheet of sand across the lake bed. The depth of erosion increases toward the north (seaward end) of the lake. A radiocarbon date from immediately above this anomalous sand layer yielded a date that, when calibrated, overlapped with the age of basin isolation at the two sigma age range $(5620 \pm 60 \mathrm{BP}, 6292-6530 \mathrm{cal}$ a $\mathrm{BP})$. Long et al. [37] briefly considered the origin of this deposit, suggesting that because the basin faces east and has a relatively protected aspect, the most obvious candidates for this incursion were either a storm surge or an exceptional wave caused by an iceberg roll-generated tsunami, or landslide-generated tsunami.
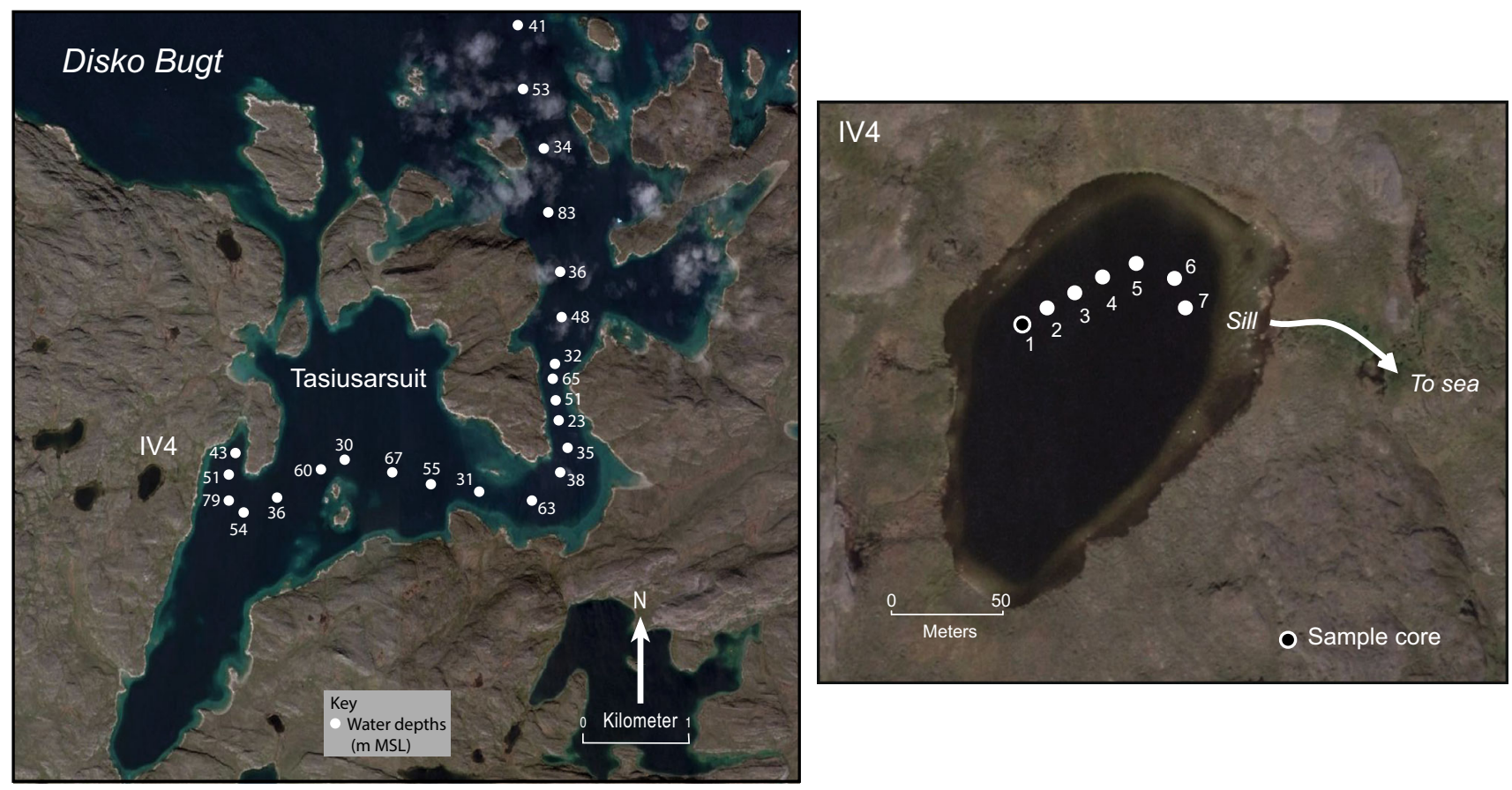

Fig. 3 The Innaarsuit study area showing lakes cored as part of the relative sea-level study of Long et al. [37]. Lake IV4 is the focus of the current paper 


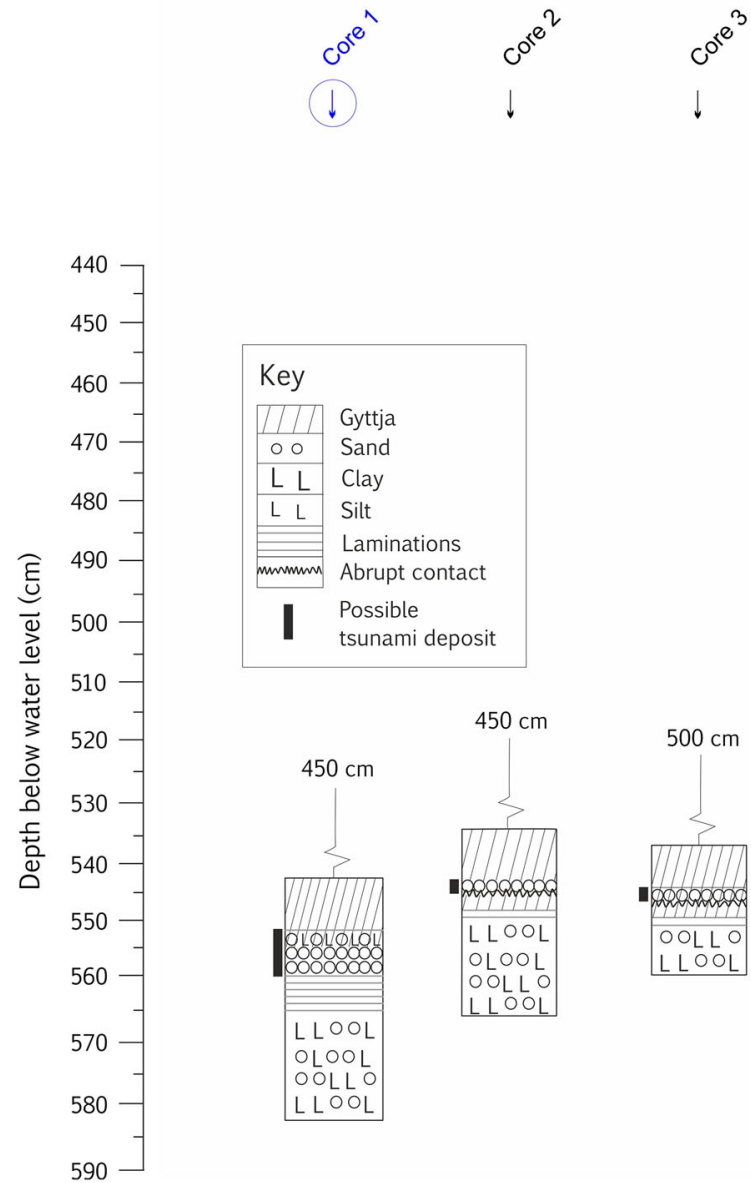

Fig. 4 The lithostratigraphy of lake IV4, identifying the anomalous deposit and the sample core (core 1) used for detailed analysis. Only the lowermost part of the stratigraphy in each core is shown; the

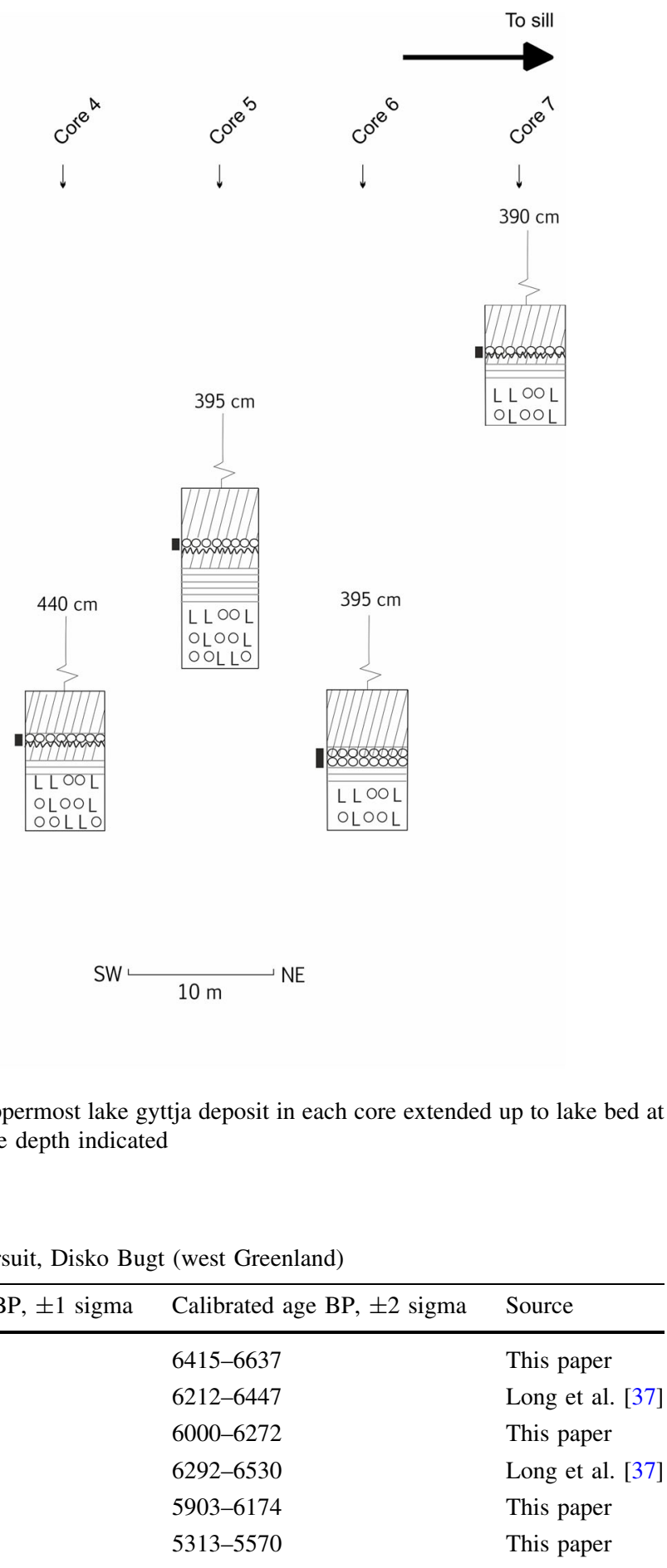

Table 1 List of radiocarbon ages from the sample core in lake IV4, Innaarsuit, Disko Bugt (west Greenland)

\begin{tabular}{llllll}
\hline Code & Mid sample depth $(\mathrm{cm})$ & Laboratory code & Radiocarbon age BP, \pm 1 sigma & Calibrated age BP, \pm 2 sigma & Source \\
\hline IV4-1 & 532.5 & Poz-53393 & $5730 \pm 40$ & $6415-6637$ & This paper \\
IV4-2 & 531.5 & AA-39652 & $5540 \pm 60$ & $6212-6447$ & Long et al. [37] \\
IV4-3 & 527.5 & Poz-53392 & $5350 \pm 40$ & $6000-6272$ & This paper \\
IV4-4 & 526 & AA-39651 & $5620 \pm 60$ & $6292-6530$ & Long et al. [37] \\
IV4-5 & 525 & Poz-53391 & $5210 \pm 40$ & $5903-6174$ & This paper \\
IV4-6 & 518 & Poz-53629 & $4665 \pm 35$ & $5313-5570$ & This paper
\end{tabular}

All dates are on 1-cm-thick bulk sediment samples. Dates are calibrated using Calib version 7.1

\section{Methods}

The original sample core was collected in July 2000 using a modified piston corer, from a small inflatable boat tethered to the lake shore. Half of the core was sampled for the initial study of Long et al. [37], with the other half wrapped in plastic and refrigerated. The latter provided the basis for the new data described in this paper.

We used a GEOTEK Multi-Sensor Core Logger (MSCL) system based in the Geography Department at Durham University to quantify a suite of geophysical measurements from the IV4 sample core. The core image 
was captured using a Geotek GEOSCAN IV line-scan camera. We use magnetic susceptibility to assess the degree of magnetization of a material in response to an applied magnetic field. Measurements were made with a Bartington loop sensor (MS2C), using a low intensity (approx. $80 \mathrm{~A} / \mathrm{m} \mathrm{RMS)}$ non-saturating, alternating magnetic field $(0.565 \mathrm{kHz})$, with values cited in SI units. The sampling interval for magnetic susceptibility was $0.2 \mathrm{~cm}$.

Samples for diatom analysis were prepared using standard methods [48], identified with reference to Hartley et al. [27] and grouped according to the halobian classification scheme of Vos and de Wolf [63, 64], with minimum counts of 200 diatom valves. The original sampling interval for diatom analysis of $1 \mathrm{~cm}$ intervals is increased to $0.25-0.5 \mathrm{~cm}$ throughout the key sections of core. Summary diatom data are presented in Fig. 5, and full data are shown in Figure S1.

The original chronology for the sequence was based on two bulk AMS radiocarbon dates on lake gyttja that dated the basin isolation from the sea and the start of gyttja sedimentation following the deposition of the anomalous sand layer. Plant macrofossils are rare in the core and so here we report a further 4 AMS dates on bulk sediment, pre-treated using standard methods (e.g. [14]) and dated at the Poznan Radiocarbon Laboratory in Poznan, Poland. Ages are calibrated (IntCal13; Reimer et al. [51]) and given as $2 \sigma$ ranges (Table 1 ). With one exception, the dates are in age sequence. We use Bayesian age modelling software OxCal 4.1 [10], utilising the $P_{-}$sequence function which allows for random fluctuations in deposition rate. The model builds prior densities for each point (priors) before building posterior (modelled) densities for each point using stratigraphic information, Bayesian algorithms and a Monte Carlo Markov Chain random sampling approach [24]. Model agreement is provided by an "agreement index" (AI), with $\mathrm{AI}>60 \%$ the accepted threshold for good agreement [11]. Our age model carries an agreement index of $89 \%$, indicating excellent internal agreement, and enables us to generate modelled ages for key stratigraphic levels (Table 2).

Grain size analysis was performed on one sample from the anomalous sand deposit, using a Malvern Mastersizer 2000 Particle Analyser on material pre-treated with hydrogen peroxide to remove organic matter, and with sodium hexametaphosphate and ultrasound prior to the analyses to avoid aggregation. Grain size statistics were calculated using the logarithmic method of moments with GRADISTAT software [5]. Organic content is expressed as percentage loss on ignition (LOI) determined by combustion of $1-\mathrm{cm}$-thick sediment slices at $550{ }^{\circ} \mathrm{C}$ for a minimum of $4 \mathrm{~h}$.
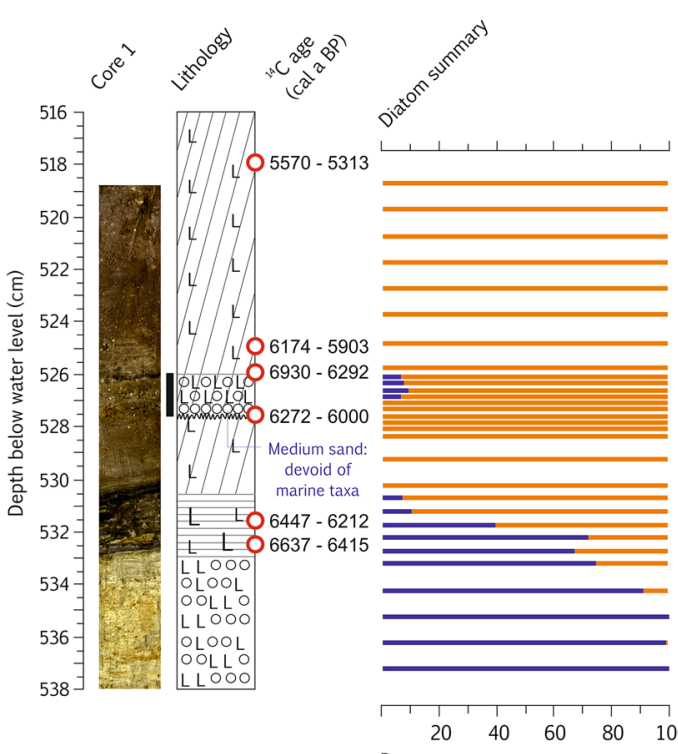

Percent

\begin{tabular}{|c|c|c|c|}
\hline 1111 & Gyttja & mminmm & Abrupt contact \\
\hline 00 & Sand & & Marine \\
\hline L L & Clay & & Fresh/indifferent \\
\hline L L & $\begin{array}{l}\text { Silt } \\
\text { Laminations }\end{array}$ & & $\begin{array}{l}\text { Possible } \\
\text { tsunami deposit }\end{array}$ \\
\hline
\end{tabular}

Fig. 5 Litho-, bio- and chronostratigraphic data from IV4 sample core (core 1). The anomalous deposit is highlighted with calibrated radiocarbon dates on the left ( 2 sigma age ranges) and modelled ages
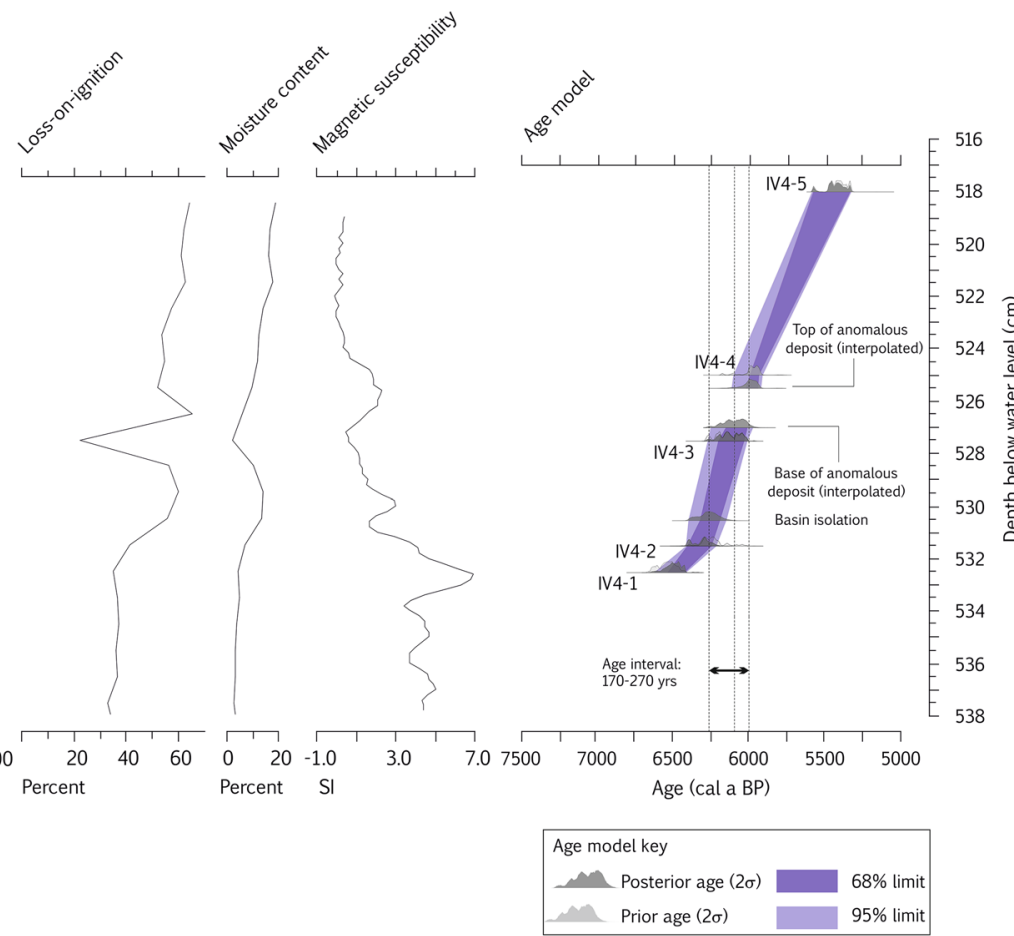

on the right. The original radiocarbon dates and the modelled ages are detailed in Tables 1 and 2, respectively 
Table 2 Modelled ages of the main events recorded in the IV4 stratigraphy based on the use Bayesian age modelling software OxCal 4.1 [10]see text for details and Fig. 4 for the age model itself

\begin{tabular}{lllll}
\hline Code & $\begin{array}{l}\text { Mid sample depth } \\
(\mathrm{cm})\end{array}$ & $\begin{array}{l}\text { Mean calibrated } \\
\text { age BP }\end{array}$ & $\begin{array}{l}\text { 95 \% probability age range } \\
\text { (cal year BP) }\end{array}$ & $\begin{array}{l}\text { 68 \% probability age range } \\
\text { (cal year BP) }\end{array}$ \\
\hline IV4-1 & 532.5 & 6487 & $6403-6614$ & $6412-6525$ \\
IV4-2 & 531.5 & 6303 & $6205-6405$ & $6236-6397$ \\
Basin isolation & 530.5 & 6256 & $6138-6388$ & $6179-6311$ \\
IV4-3 & 527.5 & 6112 & $6000-6261$ & $6021-6192$ \\
Base of sand & 527.25 & 6087 & $5963-6242$ & $6000-6143$ \\
Top of sand & 525.5 & 5984 & $5910-6104$ & $5930-6010$ \\
IV4-5 & 525 & 5957 & $5900-6093$ & $5924-5985$ \\
IV4-6 & 518 & 5420 & $5315-5575$ & $5322-5567$ \\
\hline
\end{tabular}

IV4-4 is not in age sequence and is excluded from the analysis

\section{Results}

We present the combined physical property, diatom data and age model for the sample core in Fig. 5. Overall, the sequence records four discreet episodes of environmental change that reflect the control of both short- and long-term RSL fluctuations on basin sedimentation. Below, we discuss these four episodes in turn, from older to younger.

\section{Marine (544-534 cm)}

The base of the IV4 sequence between 544 and $534 \mathrm{~cm}$ (16-26 cm core depth) comprises a blue-grey, silt-sand associated with low LOI (3\%) and moisture content (34\%) (Fig. 5). Diatom data show a marine origin for the deposit, with samples dominated by Navicula digitoradiata. Lesser assemblage contributions are provided by $G y$ rosigma balticum, Nitzschia sigma and Nitzschia apiculata. Sediment magnetic susceptibility is high, reflecting a relatively low content of diamagnetic substances (calcite, quartz, water, or organic matter). These are interpreted to be marine sediments that were deposited prior to the basins' final isolation from the sea.

\section{Basin Isolation $(\mathbf{5 3 3}-\mathbf{5 3 0 . 5} \mathrm{cm})$}

Between 533 and $531 \mathrm{~cm}(12.5-16 \mathrm{~cm}$ core depth), the sediment is a brown, organic silt-clay with black laminations that are slightly inclined, likely a result of the coring and subsequent extrusion of the sediment from the piston sample tube. Diatoms within this unit record the basins' gradual isolation from the sea, with marine taxa becoming replaced by increased frequencies of freshwater species. Key freshwater taxa include Mastogloia ovata, Rhopalodia musculus, Fragilaria virescens and Fragilaria pinnata. We define the basins' final isolation from the sea by the last occurrence of marine taxa at $530.5 \mathrm{~cm}$, dated in our age model to 6388-6138 cal year BP (Table 2). Up-core, moisture content and LOI increase across the isolation contact, indicating a switch from minerogenic to organic deposition. Conversely, sediment magnetic susceptibility undergoes a gradual decrease.

\section{Freshwater $(530.5-528 \mathrm{~cm})$}

Between 531 and $528 \mathrm{~cm}$, the sediment is a dark browngrey, silty gyttja. Diatoms within the gyttja are dominated by fully freshwater taxa, as indicated by an assemblage dominated by the freshwater-indifferent Fragilaria construens, Fragilaria virescens, Fragilaria pinnata and Fragilaria brevistriata. LOI is relatively high $(>10 \%)$ while magnetic susceptibility of sediments is low, likely reflecting increased organic matter content. Moisture content is the highest encountered in the sequence (55-60\%).

\section{“Anomalous deposit" (527.5-526)}

Overlying the freshwater gyttja between 527.5 and $526 \mathrm{~cm}$ is an anomalous deposit. The base comprises a thin $(5 \mathrm{~mm}$ thick) yellow-white silty medium sand (89.6\% of sand) rich in quartz and mica. Mean grain size is within the fine sand class (2.29 phi), the principal mode is in medium sand ( $1.49 \mathrm{phi}$ ), the sediment is poorly sorted, very fine skewed and characterised by a leptokurtic distribution. LOI sharply decreases within the sand. Immediately overlying the sand is $1 \mathrm{~cm}$ of silty gyttja. Diatom analysis shows a mixedsalinity assemblage that is dominated $(95 \%)$ by the taxa encountered in the freshwater gyttja and across the isolation contact (see above). However, a notable minor assemblage contribution (10\%) of Navicula digitoradiata and Mastogloia ovata supports a marine origin of the deposit. The top of the sequence is constrained by a single 
black laminae that we interpret reflects a return to quietwater sedimentation. Magnetic susceptibility undergoes an abrupt increase across the entire anomalous deposit, but also extends up-core by a further $1.5 \mathrm{~cm}$. In our age model (Fig. 5; Table 2), the base of the medium sand ('base of deposit') is dated to $6242-5963$ cal year BP, while the black laminae ('top of deposit') is dated to 6104-5910 cal year BP, which defines a mathematical age range of 6242-5910 for the anomalous deposit (2 sigma modelled age range).

\section{Freshwater (518-525 cm)}

The upper $7 \mathrm{~cm}$ of the section is comprised of dark browngrey, silty gyttja, recording a return to organic-dominated sedimentation and final return to freshwater conditions. Overall, the diatoms encountered are identical to those observed in the lower gyttja between 531 and $528 \mathrm{~cm}$, while LOI and moisture content is also similar, averaging 15 and $59 \%$, respectively.

\section{Discussion}

\section{Estimation of minimum flooding run-up height}

The starting point of our discussion is to quantify the minimum run-up of sea-water inundation required to deposit the anomalous sand unit observed in the IV4 lake, which we do by combining our new age model for the sequence with what we know about RSL changes at the time of the event. The rate of RSL fall during the midHolocene at Innaarssuit is well constrained by data from this site and from an adjacent site to the west; Queqertarsuatsiaat (Fig. 6) (Long and Roberts [35]). They show that RSL (MSL) fell from $31 \mathrm{~m}$ at c. $7.7 \mathrm{k}$ cal a BP to $20.3 \mathrm{~m}$ by $6.2 \mathrm{k}$ cal a BP (the date for isolation in IV4) and then continued to fall to reach c. $2 \mathrm{~m}$ by $3.9 \mathrm{k}$ cal a BP. This is equivalent to a rate of RSL fall of c. $0.81 \mathrm{~cm}$ year. We use this estimated rate of RSL fall to infer the run-up required to re-flood the IV4 basin.

The best-estimate age for basin isolation and sand deposition in IV4 have mean modelled ages of 6256 and 5984 cal a BP, respectively (Table 2); hence, there was an interval of c. 270 years between the two events. During this interval, RSL fell by c. $2.2 \mathrm{~m}$ (i.e. 270 years $\times 0.0081 \mathrm{~m}$ year), meaning the wave must have had a run-up of at least this size to ingress the basin. This estimate assumes that event struck at the same point in the tidal cycle as existed when the basin was isolated (i.e. midway between Highest Astronomical Tides and Mean High Water of Spring Tides, c. $1.05 \pm 0.59 \mathrm{~m}$ above MSL). Given that this level is high in the tidal frame and only

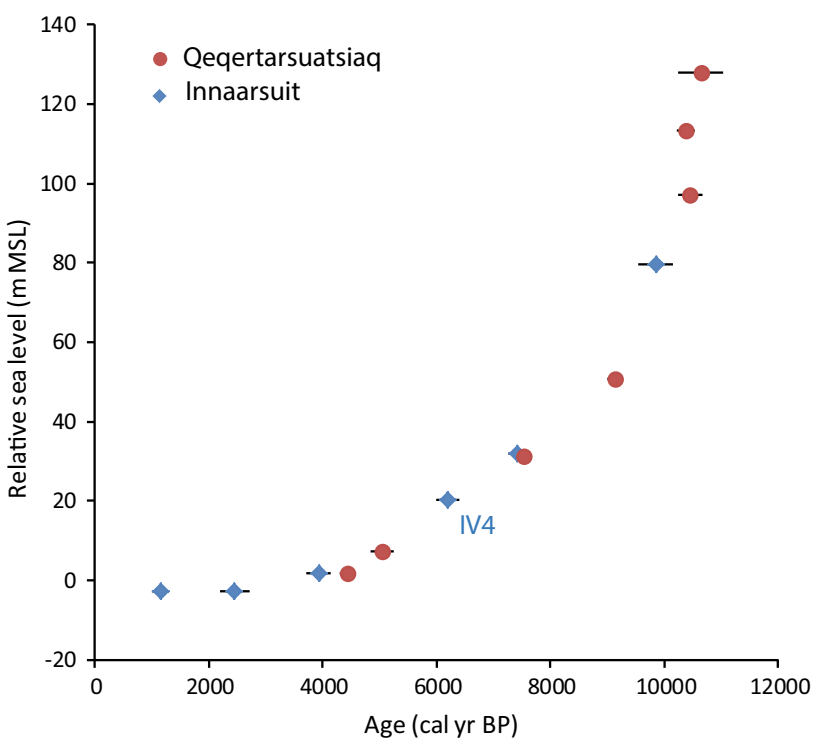

Fig. 6 Relative sea-level history of Innaarsuit and Qeqertarsuatsiaq (original data are from Long et al. [37] and Long and Roberts [35]). The $\mathrm{x}$-error uncertainties are the 2 sigma calibrated age range of each radiocarbon date, and the y-axis errors are less than the symbol sizes (see original publications for details)

reached by some of the highest tides of the year, it is more likely that the event struck at a lower tide position. This would increase the run-up required to inundate the basin. For example, if we assume that the event occurred at a point mid-way through the tide cycle, then the run-up would have been closer to $3.3 \mathrm{~m}$. These estimates are also based on median age estimates. Utilising the full $95 \%$ probability age estimates (modelled using $\mathrm{OxCal}$ ), then the estimated maximum/minimum run-up range (assuming a mid-tide cycle event) would have been c. 5.0/1.3 m.

\section{Depositional origin of the sand layer in IV4}

The original interpretation by Long et al. [37] of the anomalous sand in IV4 was equivocal regarding its depositional origin. They dismissed a non-marine origin (e.g. freshwater runoff or a slump within the lake) and noted that the most likely explanation was that it formed by either a storm surge or an exceptional wave caused by an iceberg roll-generated tsunami, or a landslide-generated tsunami.

We think an exceptional storm is unlikely as the cause of the sand unit observed in lake IV4 for several reasons. First, this is a low tidal range, protected coastal setting. The field site at the time of the event was located at the western end of a quiet-water inlet, with a maximum wind fetch (from the east) of about $3 \mathrm{~km}$ (Fig. 3). Direct observations of storm surge heights in Disko Bugt are not available, but wind speed data are available from several sites in the bay (e.g. [25]). These show that the highest wind speeds each 
year are recorded in the winter months, when strong easterly air flow from the Greenland Ice Sheet dominates. In contrast, wind speeds are generally significantly lower in the summer months and are recorded with easterly and westerly directions. Strong winter winds coincide with low air temperatures that cause sea ice to freeze, especially in protected embayments, such as the study area. Therefore, the strongest winter winds are not able to generate large wave set-up because of the frozen sea and lake surfaces in winter months. A combination of limited wave fetch, low tidal range and weak summer winds when open waters exist suggest that a large storm surge is an improbable mechanism to explain the sand deposit in IV4.

We now assess the stratigraphic evidence for the anomalous sand unit in IV4 having been formed by a tsunami, using the five criteria described by Bondevik et al. [6] from the Storegga tsunami.

(1) An erosional unconformity underlies the sand in all cores in IV4. The amount of erosion is greatest close to the sill of the basin and decreases inland, where it is recorded at progressively higher levels within the stratigraphic sequence. In core 6 , for example, close to the sill, the sand lies unconformably above the laminated sediments of the isolation contact, indicating the likely erosion of sediments that accumulated during several centuries. This pattern suggests greater turbulence near the sill and lee-side erosion caused by the erosive impact of the tsunami as it flooded over the basin sill.

(2) The sand is a medium sand composed mainly of quartz and mica, suggesting rapid deposition from suspension. Its composition likely represents local beach conditions (the source of sediment) and shows that the coast was not affected by large storm waves. Beaches within the region of the study area that are commonly affected by storms are typically characterised by much coarser sandy and gravel sediments (e.g. [18]).

(3) Immediately above the reworked gyttja in the cores 1,3 and 6 , we observe a faintly laminated unit that contains marine diatoms. We interpret this unit as forming as a result of salt-water remaining in the basin following inundation, causing a period of anoxic bottom-water conditions and reduced bioturbation. A radiocarbon date from a sample just above the sand unit is not in chronological order, suggesting that it includes older, reworked organic matter. It likely contains some of the fine-grained sediments eroded by the tsunami and deposited after the inundation that deposited the sand layer.

(4) We did not sample a staircase of vertically closely spaced basins (they do not exist), which might have enabled identification of one or more sand units. Within IV4, there is a single sand unit with no intervening organic detritus, suggesting that a single wave inundated the basin or the period between successive waves was too brief to allow permanent deposition.

(5) In contrast to the Norwegian examples, the tsunami deposit package is thin. The IV4 tsunami deposit sand unit itself is $<3 \mathrm{~cm}$ thick, whilst the laminated sediments that formed after the event are only found over only a further $1-3 \mathrm{~cm}$. It may partly reflect the relatively small size of the wave but it may be also be due to a limited source of local sediment (the present-day intertidal zone adjacent to IV4 is rocky with little beach).

On the basis of the above comparison, we interpret the anomalous sand horizon in IV4 as having been formed by a tsunami, generated by either a landslide entering the sea or the rolling of an iceberg. We note that there are no existing stratigraphic criteria to distinguish between these potential mechanisms, and instead rely on our interpretation of the topographic setting of the study site, as well as what we presently know about the magnitude and frequency of landslide- and iceberg-related events in Disko Bugt.

In Disko Bugt, the prime source areas of landslides that terminate in the sea are Vaigat and the south coast of Disko Island (Fig. 1) (Pedersen et al. [49]; [15]). A large landslide in Vaigat is unlikely to direct a tsunami of sufficient size across Disko Bugt to impact in the Innaarsuit area. For example, the Paatuut tsunami was recorded at Saqqaq, $40 \mathrm{~km}$ east of the landslide by local residents who filmed unusual waves arriving onshore. Although the initial waves were not observed, those that were recorded were only c. $1.5 \mathrm{~m}$ in height [15]. This suggests that wave refraction within Vaigat acts to significantly reduce tsunami size in Disko Bugt proper. Landslides generated from the south coast of Disko Island provide an alternative potential source of landslide-generated tsunami although there is no record of landslide-generated tsunami from this location. The area is directly opposite the Innaarsuit field site, but any wave would have had to overcome both the small skerries and islands that lie offshore of Tasiusarsuit, where it would likely amplify, but would then have been dissipated within the deeper waters of Tasiusarsuit as it approached the shore adjacent to the IV4 lake. We therefore consider a landslide tsunami, originating from Vaigat or the south coast of Disko Island, an unlikely source for the anomalous sand unit observed in lake IV4.

The second possibility is that the sand unit in IV4 originated by a tsunami that was generated by a local iceberg rolling within Tasiusarsuit. Icebergs enter Tasiusarsuit today and would have done so more freely in 
the middle Holocene, when RSL was higher than present. Based on the depth of the Tasiusarsuit inlet, the largest icebergs that were able to drift into Tasiusarsuit were probably rather small, with a maximum height of c. $45 \mathrm{~m}$ at the time of the event. Based on the simple rule of thumb proposed by MacAyeal et al. [42], were an iceberg of this size to roll, it would generate a tsunami with a wave height of c. $45 \mathrm{~cm}$ in open water, but this could have been significantly amplified in the restricted waters of the Tasiusarsuit inlet. This simple calculation supports several lines of evidence that suggest the tsunami was relatively small ( $>3 \mathrm{~m}$ run-up height), including the inferred run-up from the RSL data, the thinness of the sand unit and the limited erosion of the underlying lake sediment. We also note that the IV4 sand unit is the only evidence for marine inundation during the c. 200 year time interval when RSL fall meant that a tsunami had the chance to reach the lake. The likelihood of a local iceberg roll as the cause of this tsunami is higher than that of a landslide-generated event, since the latter happens relatively infrequently. Indeed, as noted above, the Paatuut landslide was the largest event in at least 500 years and its impact was modest beyond Vaigat with, for example, little evidence for wave disturbance at Ilulissat, a distance of c. $130 \mathrm{~km}$ from the tsunami source [15]. The south coast of Disko Bugt is c. $70 \mathrm{~km}$ from Innaarsuit and any landslide-generated wave would likewise dissipate energy crossing the bay and then entering Tasiusarsuit.

\section{Stratigraphic and morphological evidence for iceberg-generated tsunami elsewhere in Disko Bugt}

The potential for iceberg-generated tsunami is recognised elsewhere in Disko Bugt in sedimentological studies from the south coast of Disko Island, and in beach geomorphology adjacent to the marine-calving glacier Equip Sermia (Fig. 1). In a description of the coastal geomorphology of three cuspate forelands at Saqqrlitt Ilorlitt (Fig. 1), Rasch et al. [50] describe the stratigraphy of several small coastal lagoons which comprise coarse sand layers within fine-grained sandy-clayey silts. The authors suggest that some of these sand layers might have resulted from "a short but dramatic event like a washover caused by a storm, calving of a large iceberg or a tsunami".

At Equip Sermia (Fig. 1), a large marine-calving glacier in the north of Disko Bugt, Nielsen [45] describes a coarse boulder beach located $2.5 \mathrm{~km}$ from, and directly opposite, the calving front. The site is located within the inner part of a fjord system where fetch is restricted and normal waves are typically very small. Nielsen [45] concludes that "large waves generated by glacier calving, and/or sea ice action, are therefore the only processes that can explain the geomorphology and clast distribution of this coastal feature". The Equip Semia example is not directly comparable to the situation in our study of IV4, since the proposed mechanism of wave generation is the collapse of the calving ice front of the glacier. However, icebergs are frequent in front of the Equip Sermia and it would seem likely that they, as well as direct ice face collapse, have the potential to generate waves in this setting. Moreover, it is possible that the Innaarsuit wave was generated by the collapse of a grounded iceberg, as opposed to an iceberg roll-we cannot differentiate between these potential causes.

Our re-analysis of the IV4 stratigraphy, and the observations by Rasch et al. [50] and Nielsen [45], prompt us to re-analyse the stratigraphy of previously cored isolation basins elsewhere in Disko Bugt to assess whether there is evidence in any of these lakes for potential tsunami deposits. Arveprinsens Eijland is located in the northeast of Disko Bugt (Figs. 1,7) and was the site for a RSL study by Long et al. [36]. It is an ideal site to examine evidence of iceberg-generated tsunami due to the position of the sampled lakes immediately adjacent to Vaskebugt (Arveprinsens Eijland, Figs. 1, 7), a deep fjord that harbours large icebergs that drift into the bay en route from the ice sheet towards the Vaigat and Davis Strait.

Several of the lakes sampled in this area may indeed contain evidence for tsunami inwash, evidence that Long et al. [36] originally attributed to sediment slumping (e.g. [22]). For example, the basal lake sediments of basin V8 (lake sill c. $14 \mathrm{~m}$ asl, core 3) comprise a deposit of dark $\mathrm{red} / \mathrm{brown}$ turfa (rooted remains of herbaceous plants) with some detrital herbaceous matter that overlies an impenetrable substrate (Fig. 7). This is abruptly overlain by a sequence of interbedded organic silts and sands, which grade up into a homogenous lake gyttja that extends to lake bed. In two of the deeper cores, a thin, faintly laminated silt gyttja is recorded above the silts and sand. This silt gyttja unit may record anoxic conditions in the basin after a marine incursion, similar to that observed in the IV4 core and also described from Norwegian lakes following the Storegga tsunami [7]. The disturbed nature of the stratigraphy in this basin, including the presence of turfa in the stratigraphy of V8, suggests reworking of terrestrial vegetation and lake deposits by a marine incursion that flooded the basin and the adjoining land surface.

In a higher lake that was isolated in the early Holocene (V1, lake sill c. $61 \mathrm{~m}$ asl, isolated c. $9000 \mathrm{cal} \mathrm{BP}$ ), Long et al. [36] observed close to the transition between the lower marine silts and sands and the overlying freshwater gyttja a prominent horizon of coarse sand and angular gravel, between 2 and $0.5 \mathrm{~cm}$ thick (Fig. 7). In some instances, the coarse horizon is recorded immediately above the marine sediments, whilst in several cores it 


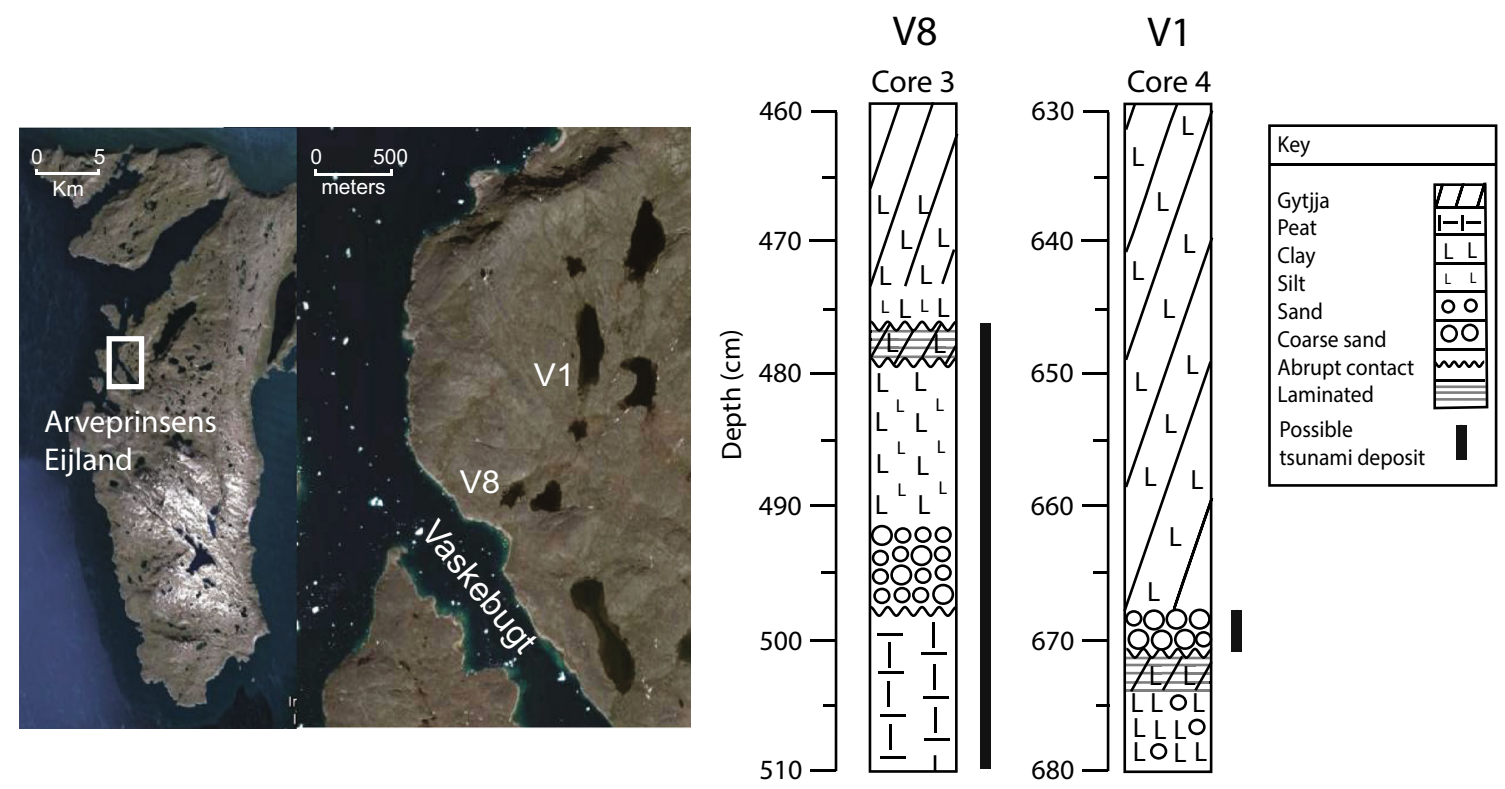

Fig. 7 Location map and representative core stratigraphies from two isolation basins sampled on Arveprinsens Eijland [36]. The core numbers refer to those reported in the original study. The potential tsunami deposits are highlighted

occurs within the base of the gyttja. Diatom data from core 2 (not shown) indicate a subtle marine influence in the sand. Viewed together, the V1 stratigraphy resembles elements of the tsunami sediment model described by Bondevik et al. [6], including the erosive base to the sand and the presence of marine diatoms in the sand.

A re-analysis of the stratigraphic data from two isolation basins on Arveprinsens Eijland suggests that they may have been impacted by tsunami during or shortly after their isolation from the sea. Arveprinsens Eijland is located close to the Nuussuaq Peninsula, a known source of landslide-triggered tsunami (Pedersen et al. [49]). However, the site is protected from the open coast to the west by a large bedrock ridge, meaning that the most likely cause of tsunami here are local icebergs. We have studied well over a hundred isolation basins in various RSL studies in Disko Bugt and elsewhere in Greenland (see [39]. Reviewing these records, we observe that only a small number have potential tsunami deposits within them. Those lakes that may preserve such evidence tend to be located adjacent to deep water and close to a source of icebergs. Our sampling strategy for RSL studies normally avoids these locations, by focussing on quiet, protected settings where a staircase of basins exists within a small geographical area. A more targeted sampling strategy towards basins located in favourable settings in Greenland or other polar regions would, we suspect, identify many more potential iceberggenerated tsunami sequences.

The potential for iceberg tsunami is likely to be higher during periods of large iceberg production, such as when marine-based portions of ice sheets retreat rapidly. One such period would have been after the Last Glacial Maximum as the ice sheets retreated across their continental shelves. Evidence for equivalent events might be expected, therefore, in lake basins in Greenland and elsewhere that were deposited close to the marine limit and which were isolated from the sea shortly after deglaciation. Such periods would potentially include iceberg-generated waves as well as those caused by direct calving from the ice sheet margin into the sea, as described from Equip Sermia [45]. However, more extensive sea ice at this time may have reduced wave heights by dissipating wave energy. Indeed, there is a trade-off between the rate of RSL change and the potential to record tsunami, because a rapidly falling RSL will quickly put many metres, or even tens of metres, between an isolation basin and sea level. For these reasons, we hypothesise that some of the best records of iceberggenerated tsunami are likely preserved in low-lying coastal basins that developed during periods when RSL was changing slowly, yet when there were still sufficient icebergs to generate tsunami. There are many such lakes along the margins of the Greenland Ice Sheet, adjacent to large marine-terminating ice streams that have been active throughout the mid and late Holocene, that have the potential to record such events.

\section{Conclusions}

Iceberg tsunamis are a potentially significant coastal hazard in arctic areas, especially where icebergs roll in topographically restricted settings and where the resulting 
waves can be amplified. We present, for the first time, a detailed stratigraphic study of a sedimentary record of an iceberg-generated tsunami from a field site in Disko Bugt. Our key conclusions are:

(1) Relative sea level fell quickly during the early- and mid-Holocene in Disko Bugt, isolating shallow embayments and rock-bound basins from the sea and converting them into lakes. This process resulted in a distinctive stratigraphic record that at its simplest comprises a marine deposit that is overlain by a mixed-salinity transitional unit and then wholly freshwater lake gyttja. Departures from the longterm trend of RSL fall, by an abrupt event such as a storm or tsunami, has the potential to disrupt this sequence and create a distinctive stratigraphic signal.

(2) Analysis of a lake basin stratigraphy (IV4) at Innaarsuit, located in a protected inlet on the south shore of Disko Bugt, reveals evidence for a distinct sand unit that interrupts the tripartite isolation basin stratigraphy noted above. The stratigraphic characteristics of this sand, and its adjacent deposits, are similar to those described by Bondevik et al. [6] based on their analysis of the sedimentary signature created by the impact of the early-Holocene Storegga tsunami on coastal lakes in Norway. We use the background trend in RSL to estimate a wave run-up of c. $3.3 \mathrm{~m}$, assuming the event happened at mid-tide cycle.

(3) We note that there are no sedimentary criteria that uniquely separate a tsunami generated by an iceberg roll or a landslide that enters the sea. In this case, however, several site factors favour an iceberg- over a landslide-origin for the tsunami, including: (1) the low frequency of large landslides in the past within Disko Bugt and an absence of any known local landslide sources within the Innaarsuit study area, (2) the limited propagation of landslide-generated waves from their main source area in Disko Bugt (Vaigat), (3) the large distance between potential landslide source areas in Disko Bugt and the Innaarsuit study area, (4) an abundance of icebergs in Disko Bugt that, under a higher than present relative sea level during the mid-Holocene, could have entered the Tasiusarsuit study area, and (5) the known ability of even relatively small icebergs to generate locally large waves in topographically restricted settings.

(4) Suitable conditions for iceberg roll, and the generation of a sedimentary record of a resulting tsunami, include an ample supply of icebergs, deep water close to the shore, a protected depositional setting, and a coastal configuration that has the potential to amplify small waves as they shallow and impact the coast.

(5) We conclude by reflecting that global warming will lead to increased calving, at a time when human use of the Arctic coast will also grow. We predict, therefore, that iceberg-generated tsunami will become a growing hazard in Arctic coastal waters, especially in areas adjacent to large, fast-flowing marine-terminating ice streams that are close to human populations or infrastructure.

\section{Acknowledgments}

Funding for the original fieldwork was supported by the NERC ARCICE thematic programme (GST022189), with two radiocarbon dates provided by NERC Radiocarbon Dating Allocation No. 836.1299. The original sample collection was made with Dr David Roberts (Durham University) but the views expressed here are those of the current authors. The re-analysis of the IV4 sediments was undertaken as part of a study funded by the Polish National Science Centre grant No. 2011/01/B/ST10/01553. We thank Frank Larsen, Anders Anker Bjørk and Kurt Kjaer for their help with the newly acquired water depth data from Tasiusarsuit, and David Tappin and an anonymous reviewer for their helpful comments on an earlier version of this paper.

Open Access This article is distributed under the terms of the Creative Commons Attribution 4.0 International License (http://crea tivecommons.org/licenses/by/4.0/), which permits unrestricted use, distribution, and reproduction in any medium, provided you give appropriate credit to the original author(s) and the source, provide a link to the Creative Commons license, and indicate if changes were made.

\section{References}

1. Amundson JM, Fahnestock M, Truffer M, Brown J, Lüthi MP, Motyka RJ (2010) Ice mélange dynamics and implications for terminus stability, Jakobshavn Isbræ, Greenland. J Geophys Res. doi:10.1029/2009JF001405

2. Amundson JM, Truffer M, Lüthi MP, Fahnestock M, West M, Motyka RJ (2008) Glacier, fjord, and seismic response to recent large calving events, Jakobshavn Isbra. Greenland. Geophys Res Lett 35:L22501. doi:10.1029/2008GL035281

3. Bennike O (2000) Palaeoecological studies of Holocene lake sediments from west Greenland. Palaeogeog Palaeoclim Palaeoecol 155:285-304

4. Bindler R, Renberg I, Appleby PG, Anderson NJ, Rose NL (2001) Mercury accumulation rates and spatial patterns in lake sediments from west Greenland: a coast to ice margin transect. Environ Sci Technol 35:1736-1741 
5. Blott SJ, Pye K (2001) GRADISTAT: a grain size distribution and statistics package for the analysis of unconsolidated sediments. Earth Surf Proc Land 26:1237-1248

6. Bondevik S, Svendsen JI, Mangerud J (1997) Tsunami sedimentary facies deposited by the Storegga tsunami in shallow marine basins and coastal lakes, western Norway. Sedimentology 44:1115-1131

7. Bondevik S, Løvholt F, Harbitz C, Mangerud J, Dawson A, Svendsen JI (2005) The Storegga Slide tsunami-comparing field observations with numerical simulations. Mar Petrol Geol 22:195-208

8. Bondevik S, Stormo SK, Skjerdal G (2012) Green mosses date the Storegga tsunami to the chilliest decades of the $8.2 \mathrm{ka}$ cold event. Quat Sci Rev 45:1-6

9. Brett CP, Zarudzki EFK (1979) Project Westmar: a shallow marine geophysical survey on the West Greenland shelf. Rap Grøn Geol Unders 87:1-27

10. Bronk Ramsey C (2001) Development of the radiocarbon calibration program OxCal. Radiocarbon 43:355-363

11. Bronk Ramsey C (2009) Bayesian analysis of radiocarbon dates. Radiocarbon 51:337-360

12. Buchwal A, Szczuciński W, Strzelecki M, Long AJ (2015) Treering structure of Salix glauca reveals evidence of a 2000 AD tsunami event in west Greenland: implications for Arctic paleotsunami and paleoecological studies. Polish Polar Res 36:51-65

13. Chalmers JA, Pulvertaft TCR, Marcussen C, Pedersen AK (1999) New insight into the structure of the Nuussuaq Basin, central West Greenland. Mar Petrol Geol 16:197-224

14. Czernik J, Goslar T (2001) Preparation of graphite targets in The Gliwice Radiocarbon Laboratory for AMS 14C dating. Radiocarbon 43:283-291

15. Dahl-Jensen T, Larsen LM, Pedersen SAS, Pedersen J, Jepsen HF, Pedersen GK, Nielsen T, Pedersen AK, Von platen-Hallermund F, Weng W (2004) Landslide and tsunami 21 November 2000 in Paatuut, west Greenland. Nat Hazards 31:277-287

16. Dawson AG, Long D, Smith DE (1988) The Storegga Slide: evidence from eastern Scotland for a possible tsunami. Mar Geol 82:271-276

17. Didenkulova I, Pelinovsky E (2011) Runup of tsunami waves in U-shaped bays. Pure Appl Geophys 168:1239-1249

18. Drewniak M, Strzelecki M, Szczuciński W (2014) Factors controlling beach development in Vaigat Strait, West Greenlandinsights from automated grain size analysis. In: Migała K (ed) Diversity and state of polar ecosystems. Results of the 35th Polar Symposium Wrocław, 5-7 of June 2014 University of Wroclaw, pp 189-203

19. Eisner WE, Törnqvist TE, Koster EA, Bennike O, van Leeuwen JFN (1995) Paleoecological studies of a Holocene lacustrine record from the Kangerlussuaq (Søndre Strømfjord) region of West Greenland. Quat Res 43:55-66

20. Foster IDL, Dawson AG, Dawson S, Lees J, Mansfield L (1993) Tsunami sedimentation sequences in the Scilly Isles, southwest England. Sci Tsunami Haz 11:35-46

21. Fredskild B (1983) The Holocene vegetational development of the Godthåbsfjord area, west Greenland. Medd Gronl Geosci 10:1-28

22. Fredskild B (1995) Palynology and sediment slumping in a high arctic Greenland lake. Boreas 24:345-354

23. Fritz HMF, Mohammed A, Yoo J (2009) Lituya Bay landslide impact generated mega-tsunami 50th anniversary. Pure App Geophys 166:153-175

24. Gilks WR, Richardson S, Spiegelhalter DJ (1996) Markov chain monte carlo in practice. Chapman and Hall, London

25. Hansen BU, Elberling B, Humlum O, Nielsen N (2006) Meteorological trends (1991-2004) at Arctic Station, Central West
Greenland $\left(69^{\circ} 15^{\prime}\right)$ in a 130 year perspective. Dan J Geog 106:45-55

26. Harbitz CB (1992) Model simulation of tsunamis generated by the Storegga Slides. Marine Geol 105:1-21

27. Hartley B, Barber HG, Carter JR, Sims PA (1996) An Atlas of British Diatoms. Biopress, Bristol, England, p 601

28. Hogan KA, Dix JK, Lloyd JM, Long AJ, Cotterill CJ (2011) Seismic stratigraphy records the deglacial history of Jakobshavn Isbrae, West Greenland. J Quat Sci 26:757-766

29. Hutchinson I, Guilbault J-P, Clague JJ, Bobrowsky PT (2004) Tsunamis and tectonic deformation at the northern Cascadia margin: a 3000-year record from Deserted Lake, Vancouver Island, British Columbia, Canada. The Holocene 10:429-439

30. Joughin I, Abdalati W, Fahnestock M (2004) Large fluctuations in speed on Greenland's Jakobshavn Isbrae glacier. Nature 432:608-610

31. Kelley SE, Briner JP, Young NE (2013) Rapid ice retreat in Disko Bugt supported by $10 \mathrm{Be}$ dating of the last recession of the western Greenland Ice Sheet. Quat Sci Rev 82:13-22

32. Kelley SE, Briner JP, Zimmermann SR (2015) The influence of ice marginal setting on early Holocene retreat rates in central West Greenland. J Quat Sci 30:271-280

33. Kempf P, Moernaut J, Van Daele M, Vermassen F, Vandoorne M, Pino W, Urruttia R, Schmidt S, Garrett E, De Batist M (2015) The sedimentary record of the 1960 tsunami in two coastal lakes on Isla de Chiloé, south central Chile. Sediment Geol 328:73-86

34. Levermann A (2011) When glacial giants roll over. Nature 472:43-44

35. Long AJ, Roberts DH (2003) Late Weichselian deglacial history of Disko Bugt, West Greenland, and the dynamics of the Jakobshavns Isbrae ice stream. Boreas 32:208-226

36. Long AJ, Roberts DH, Wright MR (1999) Isolation basin stratigraphy and Holocene relative sea-level change on Arveprinsen Eijland, Disko Bugt, West Greenland. J Quat Sci $14: 323-345$

37. Long AJ, Roberts DH, Rasch M (2003) New observations on the relative sea level and deglacial history of Greenland from Innaarsuit, Disko Bugt. Quat Res 60:162-171

38. Long AJ, Roberts DH, Simpson MJR, Dawson S, Milne GA, Huybrechts P (2008) Late Weichselian relative sea-level changes and ice sheet history in southeast Greenland. Earth Plan Sci Letts 272:8-18

39. Long AJ, Woodroffe SA, Roberts DH, Dawson S (2011) Isolation basins, sea-level changes and the Holocene history of the Greenland Ice Sheet. Quat Sci Rev 30:3748-3768

40. MacAyeal DR, Okal EA, Aster RC, Bassis JN (2009) Seismic observations of glaciogenic ocean waves (micro-tsunamis) on icebergs and ice shelves. J Glaciol 55:193-206

41. MacAyeal DR, Scambos TA, Hulbe CL, Fahnestock MA (2003) Catastrophic ice-shelf break-up by an ice-shelf-fragment capsize mechanism. J Glaciol 49:22-36

42. MacAyeal DR, Abbot DS, Sergienko OV (2011) Iceberg-capsize tsunamigenesis. Ann Glaciol 52:51-56

43. Malmquist C, Binder R, Remberg I, van Bavel B, Karlsson E, Anderson NJ, Tysklind M (2003) Time trends of selected persistent organic pollutants in lake sediments from Greenland. Environ Sci Tech 37:4319-4324

44. Monserrat S, Vilibic I, Rabinovich AB (2006) Meteotsunamis: atmospherically induced destructive ocean waves in the tsunami frequency band. Nat Hazards Earth Syst Sci 6:1035-1051

45. Nielsen N (1991) A boulder beach formed by waves from a calving glacier; Eqip Sermia, West Greenland. Boreas 21:159-168

46. Nishimura Y (2008) Volcanism-induced tsunamis and tsunamiites. In: Shiki T, Tsuji Y, Yamazaki T, Minoura K (eds) 
Tsunamiites-Features and Implications. Elsevier Science, Amsterdam, pp 163-184

47. Ozawa S, Nishimura T, Suito H, Kobayashi T, Tobita M, Imakiire T (2011) Coseismic and postseismic slip of the 2011 magnitude-9 Tohoku-Oki earthquake. Nature 475:373-376

48. Palmer AJM, Abbott WH (1986) Diatoms as indicators of sealevel change. In: Van de Plassche O (ed) Sea-level research: a manual for the collection and evaluation of data. Geo Books, Norwich, pp 457-488

49. Pedersen SAS, Dahl-Jensen T, Jepsen H, Larsen LM, Pedersen GK, Nielsen T, Pedersen AK, Weng W (2001) Fjeldskred ved Paatuut. Rep. 2001/99, Geological Survey of Denmark and Greenland, Copenhagen

50. Rasch M, Jakobsen BH, Nielsen N (1997) Geomorphology and sedimentary record of three cuspate forelands as indicators of late Holocene relative sea-level changes, Disko, West Greenland. Danish J Geog 97:33-46

51. Reimer PJ, Baillie MGL, Bard E, Bayliss A, Beck JW, Blackwell PG, Ramsey CB, Buck CE, Burr GS, Edwards RL, Friedrich M, Grootes PM, Guilderson TP, Hajdas I, Heaton TJ, Hogg AG, Hughen KA, Kaiser KF, Kromer B, McCormac FG, Manning SW, Reimer RW, Richards DA, Southon JR, Talamo S, Turney CSM, van der Plicht J, Weyhenmeye CE (2009) IntCal09 and Marine09 radiocarbon age calibration curves, 0-50,000 years cal BP. Radiocarbon 51:1111-1150

52. Rignot E, Kanagaratnam P (2006) Changes in the velocity structure of the Greenland Ice Sheet. Science 311:986-990. doi:10.1126/science. 1121381

53. Romundset A, Bondevik S (2011) Propagation of the Storegga tsunami into ice-free lakes along the southern shores of the Barents Sea. J Quat Sci 26:457-462

54. Sawai Y, Fujii Y, Fujiwara O, Kamataki T, Komatsubara J, Okamura Y, Satake K, Shishikura M (2008) Marine incursions of the past 1500 years and evidence of tsunamis at Suijin-numa, a coastal lake facing the Japan Trench. Holocene 18:517-528

55. Scambos TA, Fricker HA, Liu CC, Bohlander J, Fastook J, Sargent A, Massom R, Wu AM (2009) Ice shelf disintegration by plate bending and hydro-fracture: satellite observations and model results of the 2008 Wilkins Ice Shelf break-ups. Earth Plan Sci Letts 280:51-60

56. Subarya C, Chlieh M, Prawirodirdjo L, Avouac J-P, Bock Y, Sieh K, Meltzner AJ, Natawidjaja DH, McCaffrey R (2006) Plateboundary deformation associated with the great Sumatra-Andaman earthquake. Nature 440:46-51

57. Tappin DR, Sibley A, Horsburgh K, Daubord C, Cox D, Long D (2013) The English Channel 'tsunami' of 27 June 2011: a probable meteorological source. Weather 68:144-152

58. Wagner B, Bennike O, Klug M, Cremer H (2007) First indication of Storegga tsunami deposits from East Greenland. J Quat Sci 22:321-325

59. Weiss R, Lynett P, Wünnemann K (2015) The Eltanin impact and its tsunami along the coast of South America: insights for potential deposits. Earth Plan Sci Letts 409:175-181

60. Witter RC, Zhang Y, Wang K, Goldfinger C, Priest GR, Allan JC (2012) Coseismic slip on the southern Cascadia megathrust implied by tsunami deposits in an Oregon lake and earthquaketriggered marine turbidites. J Geophys Res 117:B10303. doi:10. 1029/2012JB009404

61. Wünnemann K, Weiss R (2015) The meteorite impact-induced tsunami hazard. Phil Trans R Soc Lond 373:20140381. doi:10. 1098/rsta.2014.0381

62. Velicogna I (2009) Increasing rates of ice mass loss from the Greenland and Antarctic ice sheets revealed by GRACE. Geophys Res Letts 36:L19503. doi:10.1029/2009GL040222

63. Vos PC, de Wolf H (1988) Methodological aspects of paleoecological diatom research in coastal areas of the Netherlands. Geol en Mijnb 67:31-40

64. Vos PC, de Wolf H (1993) Diatoms as a tool for reconstructing sedimentary environments in coastal wetlands; methodological aspects. Hydrobiol 267(270):285-296

65. Young NE, Briner JP, Stewart HA, Axford Y, Csatho B, Rood DH, Finkel RC (2011) Response of Jakobshavn Isbræ, Greenland, to Holocene climate change. Geology 39:131-134 